\title{
Biosynthesis of Coagulation Factor V by a Human Hepatocellular Carcinoma Cell Line
}

David B. Wilson, Hatem H. Salem, Jozef S. Mruk, Ikuro Maruyama, and Philip W. Majerus

Division of Hematology-Oncology, Departments of Internal Medicine and Biological Chemistry, Washington University School of Medicine, St. Louis, Missouri 63110

bstract. A human hepatocellular carcinoma line, HepG2, was found to secrete coagulation Factor V. Factor V activity in HepG2 culture fluid increased nearly linearly during a 20-h time course (5 ng Factor Va/h per $10^{6}$ cells). Thrombin treatment increased Factor $\mathrm{V}$ activity in HepG2 culture medium six- to ninefold, indicating that the medium accumulates a mixture of Factors $\mathrm{V}$ and Va. To demonstrate de novo synthesis of Factor $\mathrm{V}$, HepG2 cells were incubated in culture medium containing $\left[{ }^{35} \mathrm{~S}\right]$ methionine. Labeled Factor $\mathrm{V}$ was immunoprecipitated from the medium and was shown to co-migrate with purified plasma Factor V upon sodium dodecyl sulfate polyacrylamide gel electrophoresis and fluorography. When medium was treated with thrombin before immunoprecipitation and fluorography, the $330,000-M_{\mathrm{r}}$ $\left[{ }^{35} \mathrm{~S}\right]$ methionine-labeled Factor $\mathrm{V}$ was converted to Factor Va. Factor Va coagulant activities from HepG2 cells and human plasma were inhibited in parallel by anti-Factor $\mathrm{V}$ antibody, indicating that HepG2 and plasma Factor Va have the same intrinsic activity. If normal hepatocytes synthesize Factor $\mathrm{V}$ at the same rate as HepG2 cells, then hepatocyte secretion can account for the total Factor $V$ present in plasma. The production of Factor $\mathrm{V}$ by cultured human umbilical vein endothelial cells was also examined. Spent culture medium from endothelial cells contained only Factor $\mathrm{Va}$ and the amount was $<1 \%$ of the activity found in medium from HepG2 cells under comparable conditions. The amount of Factor $\mathrm{V}$ activity in endothelial cell culture fluid did not change with time in culture.

Received for publication 7 September 1983 and in revised form 2 November 1983.

J. Clin. Invest.

(c) The American Society for Clinical Investigation, Inc.

0021-9738/84/03/0654/05 \$1.00

Volume 73, March 1984, 654-658

\section{Introduction}

Human coagulation Factor $\mathbf{V}$ is a single-chain polypeptide $\left(330,000-M_{\mathrm{r}}\right)$ that is relatively inactive until cleaved by thrombin to form Factor $\mathrm{Va}$ (1). Cleavage of $\left[{ }^{125} \mathrm{I}\right]$ Factor $\mathrm{V}$ by thrombin produces three peptides that can be detected by autoradiography of sodium dodecyl sulfate (SDS)-polyacrylamide gels: the heavy chain $\left(110,000-M_{\mathrm{r}}\right)$, the light chain $\left(78,000-M_{\mathrm{r}}\right)$, and an activation peptide $\left(150,000-M_{\mathrm{r}}\right)(2,3)$. In the presence of $\mathrm{Ca}^{2+}$ the heavy and light chains are noncovalently associated and compose functional Factor Va $(3,4)$. This activated coagulation factor is an essential cofactor in the conversion of prothrombin to thrombin by Factor Xa. Recent studies have suggested that Factor $\mathrm{Va}$ can also act as a cofactor in the activation of protein $\mathrm{C}$ by thrombin $(5,6)$. Activated protein $\mathrm{C}$ inhibits coagulation by inactivating Factors Va $(7,8)$ and VIIIa (9) and stimulates fibrinolysis by inducing a rise in circulating tissue-type plasminogen activator (10). Thus, Factor Va may serve a dual role in coagulation, accelerating the process under some circumstances and limiting its dissemination under others.

Factor $\mathrm{V}$ is present in both the plasma and the alpha granules of platelets. A recent abstract has suggested that megakaryocytes, the platelet progenitors, synthesize the Factor $\mathrm{V}$ found in platelets (11). The cell type responsible for synthesis of plasma Factor $\mathrm{V}$ has not been clearly demonstrated. Early studies based on coagulation assays of rat liver perfusates suggested that hepatocytes were capable of Factor V synthesis (12). Recent reports, however, have indicated that bovine aortic endothelium can synthesize Factor $\mathrm{V}(13,14)$. In light of these findings we have undertaken the present study comparing the synthesis of Factor $\mathrm{V}$ by cultured human umbilical vein endothelial cells and the human hepatocellular carcinoma line HepG2. This cell line has been shown to synthesize many of the proteins secreted by nontransformed hepatocytes including albumin, complement components, fibrinogen, and vitamin K-dependent clotting factors (15-17). We report that HepG2 cells secrete significantly more Factor $\mathrm{V}$ than human endothelial cells. Moreover, the Factor $\mathrm{V}$ secreted by the hepatocellular carcinoma line is identical in size and intrinsic activity to plasma Factor V. 


\section{Methods}

Coagulation factors. Factors II and $\mathrm{X}$ were purified and activated as described elsewhere (18). Human Factor $\mathrm{V}$ was isolated by the method of Kane and Majerus (19). [ $\left.{ }^{125} \mathrm{I}\right] \mathrm{Factor} \mathrm{V}(10 \mu \mathrm{Ci} / \mu \mathrm{g})$ was prepared using $\mathrm{Na}^{125} \mathrm{I}$ (Amersham Corp., Arlington Heights, IL) and Iodogen (Pierce Chemical Co., Rockford, IL) as described previously $(6,20)$. Factor V coagulant activity was measured in a one-stage assay using purified coagulation factors (21). A unit of Factor $\mathrm{V}$ is defined as the activity in one milliliter of normal human plasma. Samples of Factor $\mathrm{V}$ activated by thrombin $\left(0.5 \mathrm{U} / \mathrm{ml}, 10 \mathrm{~min}, 37^{\circ} \mathrm{C}\right)$ were diluted sufficiently to avoid interference by thrombin in the assay.

Antibodies. Human anti-Factor $\mathrm{V}$ serum was from a patient who developed a monoclonal anti-Factor $\mathrm{V}$ antibody (22). IgG from control and anti-Factor $\mathrm{V}$ serum was purified using protein A-Sepharose (Pharmacia Fine Chemicals, Piscataway, NJ) (23).

Cell culture. Human umbilical vein endothelial cells were isolated by the method of Jaffe et al. (24) and grown in a $5 \% \mathrm{CO}_{2}$ atmosphere in medium 199 (KC Biological, Kansas City, MO) containing 10\% human serum (Flow Laboratories Inc., Rockville, MD), $2 \mathrm{mM}$ glutamine (Gibco Laboratories, Grand Island, NY), $100 \mathrm{U} / \mathrm{ml}$ penicillin, and $100 \mu \mathrm{g} / \mathrm{ml}$ streptomycin (Gibco Laboratories). HepG2 cells were obtained from the Wistar Institute and grown in a 5\% $\mathrm{CO}_{2}$ atmosphere using minimal essential medium-alpha (Washington University Cancer Center) supplemented with $10 \%$ fetal calf serum (KC Biological), $2 \mathrm{mM}$ glutamine, $100 \mathrm{U} / \mathrm{ml}$ penicillin, and $100 \mu \mathrm{g} / \mathrm{ml}$ streptomycin. To determine cell number, cells were harvested with trypsin, lysed with cetrimide, and the nuclei counted using a Coulter Counter model F (Coulter Electronics, Inc., Hialeah, FL) (25).

Immunoprecipitation of Factor $V$. Samples of ${ }^{125} \mathrm{I}$-Factor $\mathrm{V}$ or $\left[{ }^{35} \mathrm{~S}\right]$ methionine-labeled HepG2 culture medium were diluted to $5 \mathrm{ml}$ with $50 \mathrm{mM}$ Tris- $\mathrm{HCl}$, pH 7.6, $100 \mathrm{mM} \mathrm{NaCl}, 0.02 \% \mathrm{NaN}_{3}, 10 \mathrm{mM}$ benzamidine, $0.05 \%$ Nonidet $\mathrm{P}-40,5 \mathrm{mg} / \mathrm{ml}$ bovine serum albumin, and $10 \mathrm{mM}$ EDTA or $3 \mathrm{mM} \mathrm{CaCl}_{2}$ as indicated in the figure legends. Anti-Factor V IgG $(10 \mu \mathrm{g})$ and $20 \mu \mathrm{l}$ of packed protein A-Sepharose beads were added, and the suspensions were mixed for $5 \mathrm{~h}$ at room temperature. The beads were recovered by centrifugation and washed five times with $5 \mathrm{ml}$ of the above buffer. Adsorbed proteins were eluted from the beads by heating $3 \mathrm{~min}$ at $100^{\circ} \mathrm{C}$ in $80 \mu \mathrm{l}$ of $4 \% \mathrm{SDS}, 10 \%$ 2-mercaptoethanol, $20 \%$ glycerol, and $0.01 \%$ bromphenol blue. Discontinuous SDS-polyacrylamide gel electrophoresis of eluted proteins was carried out using the system of Laemmli (26) with $4 \%$ acrylamide in the stacking gel and $7.5 \%$ acrylamide in the resolving gel.

\section{Results}

Table I compares the Factor $\mathrm{V}$ activity found in the culture supernatants of HepG2 and human endothelial cells after a 5$h$ incubation in serum-free medium. Spent HepG2 cell culture medium contained significantly more Factor $\mathrm{V}$ activity than endothelial cell culture medium. The amount of Factor $V$ activity in endothelial cell supernatants was at the limit of sensitivity of the coagulation assay and was $\sim 100$ times less than the activity in HepG2 cell supernatants. The low level of activity in the endothelial cell culture medium was not due to the presence of an inhibitor, as shown by the mixing experiments in Table I. Activity in the endothelial cell culture medium may represent residual Factor Va from the $10 \%$ human serum used
Table I. Factor V Coagulant Activity in Tissue Culture Supernatants from HepG2 and Human Umbilical Vein Endothelial Cells

\begin{tabular}{|c|c|c|c|c|c|c|c|c|}
\hline & \multicolumn{8}{|c|}{ Factor $\mathrm{V}$ activity $(\mathrm{mU} / \mathrm{ml})$} \\
\hline & \multicolumn{2}{|c|}{ Exp. 1} & \multicolumn{2}{|c|}{ Exp. 2} & \multicolumn{2}{|c|}{ Exp. 3} & \multicolumn{2}{|c|}{ Exp. 4} \\
\hline & - thr & + thr & - thr & + thr & $-\mathrm{thr}$ & + thr & - thr & thr \\
\hline HepG2 supernatants & 16 & 80 & 6.2 & 39 & 5.1 & 52 & 10 & 150 \\
\hline $\begin{array}{l}\text { Endothelial cell } \\
\text { supernatants }\end{array}$ & 0.6 & 0.7 & 0.2 & 0.5 & ND & ND & ND & ND \\
\hline $\begin{array}{l}\text { 1:1 Mixture of } \\
\text { supernatants from } \\
\text { HepG } 2 \text { and } \\
\text { endothelial cells }\end{array}$ & 8.1 & 41 & 3.0 & 20 & ND & ND & ND & ND \\
\hline
\end{tabular}

Nearly confluent $60-\mathrm{mm}$ Petri dishes of HepG2 and endothelial cells $\left(2.5 \times 10^{6}\right.$ and $2.0 \times 10^{6}$ cells, respectively) were incubated for $5 \mathrm{~h}$ in $2 \mathrm{ml}$ of serum-free medium (minimum essential medium-alpha and medium 199, respectively). The media were harvested, frozen at $-70^{\circ} \mathrm{C}$, and subsequently assayed for Factor $\mathrm{V}$ activity in the presence and absence of thrombin activation. Values represent the mean of duplicate determinations. ND, not determined; thr, thrombin.

to grow the cells, since Factor $\mathrm{V}$ activity in endothelial cell supernatants was not enhanced by thrombin treatment (Table I) and did not change over the course of a 10-h incubation (data not shown). A time course of secretion of Factor $\mathrm{V}$ activity by HepG2 cells is shown in Fig. 1. There was a nearly linear increase in Factor $\mathrm{V}$ activity in the culture medium during the 20-h

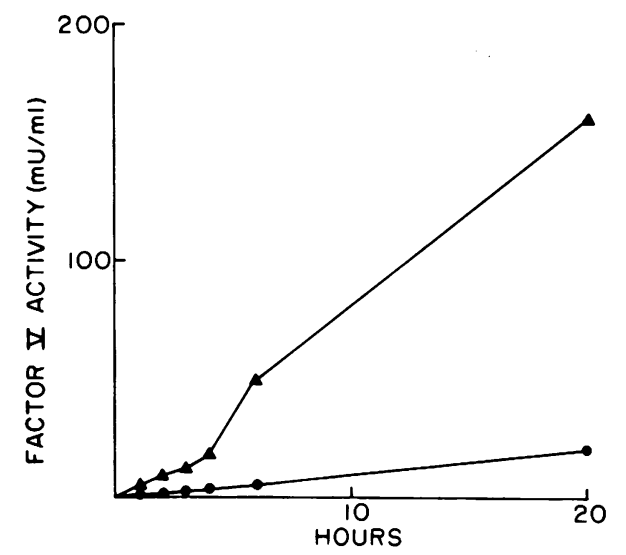

Figure 1. Time course of synthesis of Factor $\mathrm{V}$ coagulant activity by HepG2 cells. A flask $\left(25 \mathrm{~cm}^{2}\right)$ of nearly confluent HepG2 cells $(\sim 6$ $\times 10^{6}$ cells) was incubated with $7 \mathrm{ml}$ of serum free minimum essential medium-alpha. At various time points, $100-\mu 1$ samples of the medium were removed and frozen at $-70^{\circ} \mathrm{C}$. The following day the samples were assayed for Factor $\mathrm{V}$ activity in the presence $(\boldsymbol{\Delta})$ and absence $(\bullet)$ of thrombin activation. 
incubation. Throughout the time course, activity in samples of the medium was augmented six-to ninefold by thrombin treatment. Plasma Factor V can be activated 20-30-fold by thrombin, implying that the Factor $\mathrm{V}$ activity in the HepG2 culture medium was a mixture of Factors $\mathrm{V}$ and $\mathrm{Va}$. This suggests that there was some proteolytic activation of secreted Factor $\mathrm{V}$ in the HepG2 culture medium.

We estimated the rate of secretion of Factor $\mathrm{V}$ by converting it to Factor Va to obtain uniform coagulation activity. The activity of Factor $\mathrm{Va}$ is assumed to be $1.5 \mathrm{U} / \mu \mathrm{g}$ protein (19). The rate of secretion of Factor $\mathrm{V}$ into culture medium varied considerably from experiment to experiment, as shown in Table I (range 2-25 ng Factor $\mathrm{Va} / 10^{6}$ cells per $\mathrm{h}$ ). The mean rate of secretion was $5 \mathrm{ng}$ Factor $\mathrm{Va} / 10^{6}$ cells per $\mathrm{h}$.

A human monoclonal anti-Factor $\mathrm{V}$ antibody was used to immunoprecipitate Factor $V$ from labeled HepG2 medium. This antibody binds both Factor $\mathrm{V}$ and $\mathrm{Va}$ and recognizes an antigenic determinant on the light chain of Factor Va, as shown in Fig. $2 A$. In the presence of $\mathrm{Ca}^{2+}$, the 78,000-M light chain doublet and to a lesser degree the $110,000-M_{\mathrm{r}}$ heavy chain of plasma Factor $\mathrm{V}$ were immunoprecipitated by this antibody. When

A

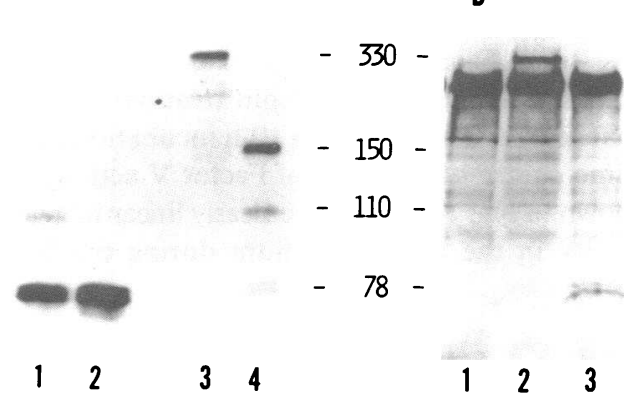

Figure 2. $(A)$ Monoclonal anti-Factor $\mathrm{V}$ antibody recognizes Factor Va light chain. [ $\left.{ }^{125} \mathrm{I}\right]$ Factor $\mathrm{V}(0.5 \mu \mathrm{g})$ was activated by thrombin $(2$ $\mathrm{U} / \mathrm{ml}, 5 \mathrm{~min}, 37^{\circ} \mathrm{C}$ ) and then immunoprecipitated using anti-Factor $\mathrm{V}$ antibody and protein A-Sepharose as described in Methods. An autoradiograph of an SDS-polyacrylamide gel of the immunoprecipitates is shown. Lane 1 , immunoprecipitation of $\left.{ }^{125} \mathrm{I}\right]$ Factor $\mathrm{Va}$ in the presence of $3 \mathrm{mM} \mathrm{CaCl}_{2}$; lane 2, immunoprecipitation of [ [25I]Factor $\mathrm{Va}$ in the presence of $10 \mathrm{mM}$ EDTA; lane 3, [ $\left.{ }^{125} \mathrm{I}\right]$ Factor $\mathrm{V}$; lane 4, [ ${ }^{125}$ I]Factor Va. $(B)$ Immunoprecipitation of Factor $V$ from ${ }^{35}$ S]methionine-labeled HepG2 culture medium. A nearly confluent flask $\left(75 \mathrm{~cm}^{2}\right)$ of HepG2 cells $\left(\sim 2 \times 10^{7}\right.$ cells $)$ was incubated for $2 \mathrm{~h}$ in methionine-deficient minimum essential medium-alpha. This medium was replaced with $5 \mathrm{ml}$ of methionine-deficient minimum essential medium-alpha containing $200 \mu \mathrm{Ci} / \mathrm{ml}\left[{ }^{35} \mathrm{~S}\right]$ methionine (New England Nuclear, $1240 \mathrm{Ci} / \mathrm{mmol})$. After $5 \mathrm{~h}$ of incubation, the medium was harvested and Factor $\mathrm{V}$ was immunoprecipitated from 1$\mathrm{ml}$ samples of medium in the presence of EDTA as described in Methods. SDS-polyacrylamide gels of the samples were fixed, treated with ENHANCE (New England Nuclear), dried, and fluorographed. Lane 1, control human IgG immunoprecipitate; lane 2, anti-Factor $\mathrm{V}$ immunoprecipitate; lane 3, anti-Factor $\mathrm{V}$ immunoprecipitate, medium treated with thrombin $\left(2 \mathrm{U} / \mathrm{ml}, 5 \mathrm{~min}, 37^{\circ} \mathrm{C}\right)$ before immunoprecipitation.
EDTA was substituted for $\mathrm{Ca}^{2+}$ in the immunoprecipitation mixture, only the light chain was immunoprecipitated. Fig. 2 $B$ shows the immunoprecipitation of Factor $V$ from $\left[{ }^{35}\right.$ S]methionine-labeled HepG2 culture medium. A 220,000$M_{\mathrm{r}}$ protein, probably fibronectin, was present in both control and anti-Factor $\mathrm{V}$ antibody immunoprecipitates. This protein is made in large quantities by HepG2 cells and contaminates all immunoprecipitates. Anti-Factor $\mathrm{V}$ antibody immunoprecipitated a $330,000-M_{\mathrm{r}}$ protein which co-migrated with purified plasma Factor V. Thrombin treatment of the labeled culture medium before the addition of antibody caused the 330,000$M_{\mathrm{r}}$ band to diminish and the $78,000-M_{\mathrm{r}}$ doublet of Factor $\mathrm{Va}$ light chain to appear, verifying that the $330,000-M_{\mathrm{r}}$ protein was Factor V. As shown in Fig. 3, a control IgG immunoprecipitate of thrombin-treated culture medium did not contain a 78,000$M_{\mathrm{r}}$ band. Immunoprecipitation of the labeled $330,000-M_{\mathrm{r}}$ and $78,000-M_{\mathrm{r}}$ bands was diminished by the addition of unlabeled Factor V (or Va) to the immunoprecipitation mixture (Fig. 3).

Fig. 4 shows that HepG2-derived Factor Va and plasma Factor Va activities were inhibited in parallel by increasing amounts of anti-Factor V IgG. This indicates that plasma Va and HepG2 Va share a common antigenic determinant and have the same intrinsic activity in a coagulation assay. On the basis of the results of Fig. 4 and a protein assay of the HepG2 culture supernatant, we estimate that Factor $V$ comprises $\sim 0.1 \%$ of the total protein secreted by this cell line.

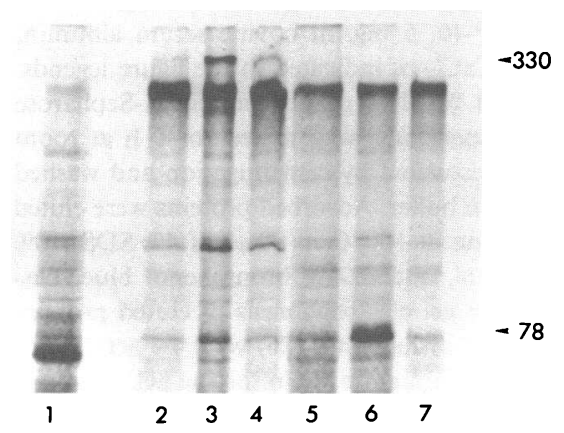

Figure 3. Immunoprecipitation of Factor V from labeled HepG2 medium is blocked by unlabeled Factor V. A nearly confluent flask ( 75 $\mathrm{cm}^{2}$ ) of HepG2 cells was incubated for $2 \mathrm{~h}$ in methionine-deficient minimal essential medium-alpha. This medium was replaced with 6 $\mathrm{ml}$ of methionine-deficient minimal essential medium-alpha containing $800 \mu \mathrm{Ci}\left[{ }^{35} \mathrm{~S}\right]$ methionine. After $6 \mathrm{~h}$ of incubation, the medium was harvested and Factor $\mathrm{V}$ was immunoprecipitated from $1 \mathrm{ml}$ samples of medium in the presence of EDTA as described in Methods. SDS-polyacrylamide gels of the samples were fixed, treated with ENHANCE, dried, and fluorographed. Lane 1, spent culture medium; lane 2, control human IgG immunoprecipitate; lane 3, anti-Factor $\mathrm{V}$ immunoprecipitate; lane 4, anti-Factor $\mathrm{V}$ immunoprecipitate in the presence of $300 \mu \mathrm{g}$ unlabeled Factor V; lane 5, control human IgG immunoprecipitate of thrombin treated $\left(2 \mathrm{U} / \mathrm{ml}, 5 \mathrm{~min}, 37^{\circ} \mathrm{C}\right) \mathrm{me}-$ dium; lane 6, anti-Factor $\mathrm{V}$ immunoprecipitate of thrombin-treated medium; lane 7, anti-Factor $\mathrm{V}$ immunoprecipitate of thrombintreated medium containing $300 \mu \mathrm{g}$ unlabeled Factor Va. 


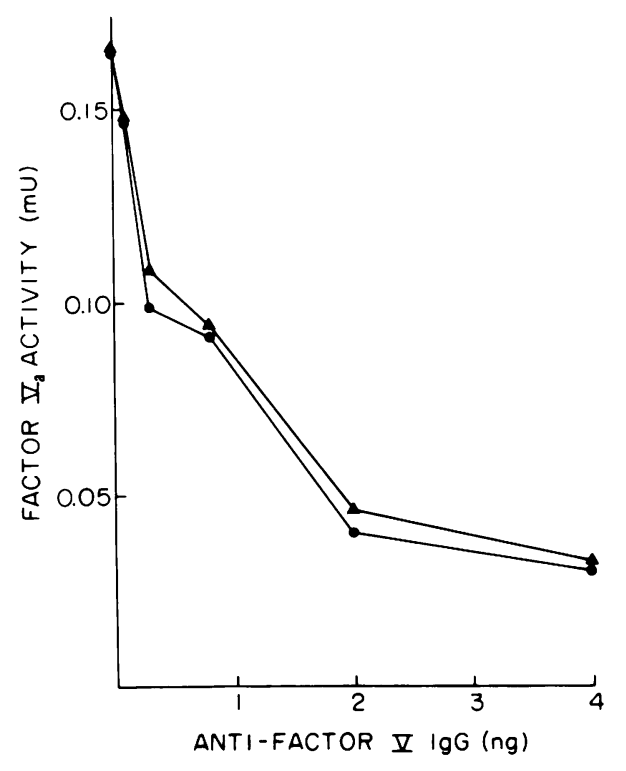

Figure 4. Inhibition of HepG2 and plasma Factor Va coagulant activities by anti-Factor $\mathrm{V}$ antibody. HepG2 culture medium was obtained by incubating a T-75 flask containing $\sim 2 \times 10^{7}$ cells for $5 \mathrm{~h}$ with $5 \mathrm{ml}$ of serum-free minimum essential medium-alpha. The harvested medium was activated with thrombin and diluted 1:60 in 10 $\mathrm{mM}$ Tris- $\mathrm{HCl} \mathrm{pH} 7.6,150 \mathrm{mM} \mathrm{NaCl}, 3 \mathrm{mM} \mathrm{CaCl}, 5 \mathrm{mg} / \mathrm{ml}$ bovine serum albumin. Purified plasma Factor $\mathrm{V}$ was activated by thrombin and diluted in $10 \mathrm{mM}$ Tris, $\mathrm{pH} 7.6,150 \mathrm{mM} \mathrm{NaCl}, 3 \mathrm{mM}$ $\mathrm{CaCl}_{2}, 5 \mathrm{mg} / \mathrm{ml}$ bovine serum albumin to give the same activity as the diluted HepG2 medium (a final Factor Va concentration of 3.4 $\mathrm{mU} / \mathrm{ml})$. Samples $(50 \mu \mathrm{l})$ of the diluted HepG2 and plasma Factor $V a$ were incubated $15 \mathrm{~min}$ at $37^{\circ} \mathrm{C}$ with varying amounts of monoclonal anti-Factor V IgG in a final volume of $60 \mu \mathrm{l}$ and then assayed for Factor $\mathrm{V}$ coagulant activity. The ordinate gives the total activity remaining in the mixtures of antibody and plasma Factor $\mathrm{Va}(\boldsymbol{\Delta})$ or HepG2 Factor Va (•).

\section{Discussion}

Several lines of evidence have suggested that plasma Factor $\mathbf{V}$ is synthesized by hepatocytes. Factor $\mathrm{V}$ activity has been detected in rat liver perfusates (12), and plasma Factor $V$ has been shown to be decreased in patients with liver disease (27). Giddings et al. (28) have localized Factor $V$ to the cytoplasm of human liver parenchymal cells using a fluorescent antibody technique. To date, however, there has been no direct demonstration of Factor $\mathrm{V}$ synthesis and secretion by hepatocytes. In this paper we have shown that Factor $\mathrm{V}$ is synthesized by a hepatocellular carcinoma line that secretes many of the proteins of normal hepatocytes. The Factor $\mathrm{V}$ secreted by this cell line is identical in size and specific activity to plasma Factor V. Assuming the rate of secretion of Factor $V$ by these transformed cells $\left(\sim 5 \mathrm{ng} / 10^{6}\right.$ cells per $h$ ) is similar to the rate of secretion by normal hepatocytes, liver synthesis is sufficient to account for the amount of Factor $\mathrm{V}$ present in plasma.

1. This calculation assumes plasma volume $=2.81$, plasma Factor $\mathrm{V}$ $=10 \mu \mathrm{g} / \mathrm{ml}, \mathrm{t}_{1 / 2}$ Factor $\mathrm{V}=16 \mathrm{~h}(29)$, Factor $\mathrm{Va}=1.5 \mathrm{U} / \mu \mathrm{g}$, and an adult human liver $=3 \times 10^{11}$ hepatocytes.
Recent reports have suggested that cultured bovine aortic endothelium is capable of Factor V synthesis. Rodgers and Shuman (14) have noted that bovine aortic endothelial cells grown in serum-free medium activate prothrombin in the presence of Factor $\mathrm{Xa}$ and $\mathrm{Ca}^{2+}$ and that this activation is inhibited by antibovine Factor V antibody. Cerveny et al. (13) have documented Factor V secretion by bovine aortic endothelium using bioassay, radioimmunoassay, and immunoprecipitation of labeled Factor $\mathrm{V}$ from cells pulsed $4 \mathrm{~d}$ with $\left.{ }^{35} \mathrm{~S}\right]$ methionine.

To determine whether these observations on bovine endothelial cells could be extended to the human system, we have examined the secretion of Factor $\mathrm{V}$ by human umbilical vein endothelial cells. Our results suggest that these cells secrete little if any Factor $\mathrm{V}$ into the medium compared with HepG2 cells. While we have not examined human aortic endothelial cells, it seems unlikely that they synthesize a significant part of the circulating Factor V.

Factor $\mathrm{V}$ has been shown to be associated with other cell types besides hepatocytes and endothelial cells. Platelet alpha granules contain Factor V, and guinea pig megakaryocytes have been shown to synthesize Factor V (11). Recently Tracy et al. (30) have detected Factor $\mathrm{V}$ in monocytes and lymphocytes using a radioimmunoassay. Whether these cells synthesize Factor $\mathrm{V}$ or somehow acquire it from plasma remains to be elucidated.

\section{Acknowledgments}

We thank Andy Chan for his assistance with the HepG2 cell line and Mike Laposata for his advice on endothelial cell culture.

This research supported by grants HLBI-14147 (Specialized Center in Thrombosis) and HL 16634 from the National Institutes of Health, by National Institutes of Health Research Service Award GM 07200, Medical Scientist, from the National Institute of General Medical Sciences, and by a grant from Monsanto Chemical Corporation.

\section{References}

1. Jackson, C. M., and Y. Nemerson. 1980. Blood coagulation. Ann. Rev. Biochem. 49:765-811.

2. Kane, W. H., and P. W. Majerus. 1982. The interaction of human coagulation factor $\mathrm{V}_{\mathrm{a}}$ with platelets. J. Biol. Chem. 257:3963-3969.

3. Suzuki, K., B. Dahlback, and J. Stenflo. 1982. Thrombin-catalyzed activation of human coagulation factor F. J. Biol. Chem. 257:65566564.

4. Esmon, C. T. 1979. The subunit structure of thrombin activated factor $\mathrm{V}$ : isolation of activated factor $\mathrm{V}$, separation of subunits, and reconstitution of biological activity. J. Biol. Chem. 254:964-973.

5. Salem, H. H., G. J. Broze, J. P. Miletich, and P. W. Majerus. 1983. Human coagulation factor $\mathrm{V}_{\mathrm{a}}$ is a cofactor for the activation of protein C. Proc. Natl. Acad. Sci. USA. 80:1584-1588.

6. Salem, H. H., G. J. Broze, J. P. Miletich, and P. W. Majerus. 1983. The light chain of factor $\mathrm{V}_{\mathrm{a}}$ contains the activity of factor $\mathrm{V}_{\mathrm{a}}$ that accelerates protein $\mathrm{C}$ activation by thrombin. J. Biol. Chem. 258:85318534.

7. Canfield, W., M. Nesheim, W. Kisiel, and K. G. Mann. 1978. Proteolytic inactivation of bovine factor $\mathrm{V}_{\mathrm{a}}$ by bovine activated protein C. Circulation. 58(Suppl. 2):210. (Abstr.)

8. Walker, F. J., P. W. Sexton, and C. T. Esmon. 1979. The inhibition 
of blood coagulation by activated protein $C$ through the selective inactivation of activated factor V. Biochim. Biophys. Acta. 571:333-342.

9. Vehar, G. A., and E. W. Davie. 1980. Preparation and properties of bovine factor VIII. Biochemistry. 19:401-409.

10. Comp, P. C., and C. T. Esmon. 1981. Generation of fibrinolytic activity by infusion of activated protein $\mathrm{C}$ into dogs. $\mathrm{J}$. Clin. Invest. 68:1221-1228.

11. Chiu, C., P. Schick, and R. W. Colman. 1983. Biosynthesis of coagulation factor V by megakaryocytes. Fed. Proc. 42:1994. (Abstr.)

12. Olson, J. P., L. L. Miller, and S. B. Troup. 1966. Synthesis of clotting factors by the isolated perfused rat liver. J. Clin. Invest. 45:690701.

13. Cerveny, T. J., D. N. Fass, and K. G. Mann. 1983. Coagulation factor V synthesis by cultured endothelium. Fed. Proc. 42:1032. (Abstr.)

14. Rodgers, G. M., and M. A. Shuman. 1983. Prothrombin is activated on vascular endothelial cells by factor $\mathrm{Xa}$ and calcium. Proc. Natl. Acad. Sci. USA. 80:7001-7005.

15. Munns, T. W., H. F. Sims, and A. W. Strauss. 1983. Biosynthesis of human prothrombin in cultured hepatoma cells. Fed. Proc. 42:1010 (Abstr.)

16. Morris, K. M., D. P. Aden, B. B. Knowles, and H. R. Colten. 1982. Complement biosynthesis by the human hepatoma-derived cell line HepG2. J. Clin. Invest. 70:906-913.

17. Knowles, B. B., C. C. Howe, and D. P. Aden. 1980. Human hepatocellular carcinoma cell lines secrete the major proteins and hepatitis B surface antigen. Science (Wash. DC). 209:497-499.

18. Miletich, J. P., G. J. Broze, and P. W. Majerus. 1980. The synthesis of sulfated dextran beads for isolation of human plasma coagulation factors II, IX, and X. Anal. Biochem. 105:304-310.

19. Kane, W. H., and P. W. Majerus. 1981. Purification and characterization of human coagulation factor V. J. Biol. Chem. 256:10021007.
20. Fraker, P. J., and J. C. Speck. 1978. Protein and cell membrane iodinations with a sparingly soluble chloroamide, 1,3,4,6-tetrachloro3 $\alpha$-diphenylglycouril. Biochem. Biophys. Res. Commun. 80:849-857.

21. Miletich, J. P., D. W. Majerus, and P. W. Majerus. 1978. Patients with congenital factor $\mathrm{V}$ deficiency have decreased factor $\mathrm{X}_{\mathrm{a}}$ binding sites on their platelets. J. Clin. Invest. 62:826-831.

22. Coots, M. C., A. F. Muhleman, and H. Y. Glueck. 1978. Hemorrhagic death associated with a high titer factor $\mathrm{V}$ inhibitor. Am. J. Hematol. 4:193-206.

23. Hjelm, H., K. Hjelm, and J. Sjoquist. 1972. Protein A from Staphylococcus aureus. Its isolation by affinity chromatography and its use as an immunosorbent for isolation of immunoglobulins. FEBS (Fed. Eur. Biochem. Soc.) Lett. 28(1):73-76.

24. Jaffe, E. A., R. L. Nachman, C. G. Becker, and C. R. Minick. 1973. Culture of human endothelial cells derived from umbilical veins. J. Clin. Invest. 52:2745-2756.

25. Laposata, M., S. M. Prescott, T. E. Bross, and P. W. Majerus. 1982. Development and characterization of a tissue culture cell line with essential fatty acid deficiency. Proc. Natl. Acad. Sci. USA. 79:76547658.

26. Laemmli, U. K. 1970. Cleavage of structural proteins during the assembly of the head of bacteriophage T4. Nature (Lond.) 227:680685 .

27. Lechner, K., H. Niessner, and E. Thaler. 1977. Coagulation abnormalities in liver disease. Sem. Thromb. Hemostasis. 4:40-56.

28. Giddings, J. C., S. A. M. Shearn, and A. L. Bloom. 1975. The immunological localization of factor $\mathrm{V}$ in human tissue. Br. J. Hematol. 29:57-65.

29. Bowie, E. J. W., J. H. Thompson, P. Dudisheim, and C. A. Owen. 1967. Disappearance rates of coagulation factors: transfusion studies in factor-deficient patients. Transfusion. 7(3):174-184.

30. Tracy, P. B., M. S. Rohrbach, and K. G. Mann. 1983. Functional prothrombinase complex assembly on isolated monocytes and lymphocytes. J. Biol. Chem. 258:7264-7267. 